УДК 621.914.1

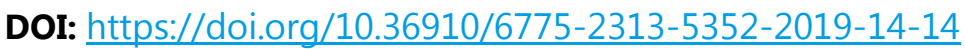

V. Marchuk, S. Hryniuk, I. Marchuk, T.Dzhuhuryan ${ }^{1}$

Lutsk National Technical University

${ }^{1}$ Shetsin Maritime Academy (Poland)

\title{
SIMULATION OF DIMENSIONAL ACCURACY IN AN AUTOMATED GRINDING SYSTEM OF SURFACES OF ROTATION
}

We consider the impact on the quality of polished surfaces forming their dimensional accuracy in operations grinding roller rings. The process for automated cutting grinding machines can be considered as an inertial link. The total error handling in grinding operations is complex.

Keywords: error, roller bearings, grinding, precision, detail

Formulation. The quality of the polished surfaces of evaluated a number of factors: the accuracy of the main dimensions, precision geometry details microstructure surface temperature prypalyuvannya defects, cracks, internal stress, and a range of physical and mechanical properties [1]. However, to determine the relationship of a controlled quantity of all the quality indicators is problematic.

Fig. 1 shows the factors affecting the performance as deviations from the set values [2,3].

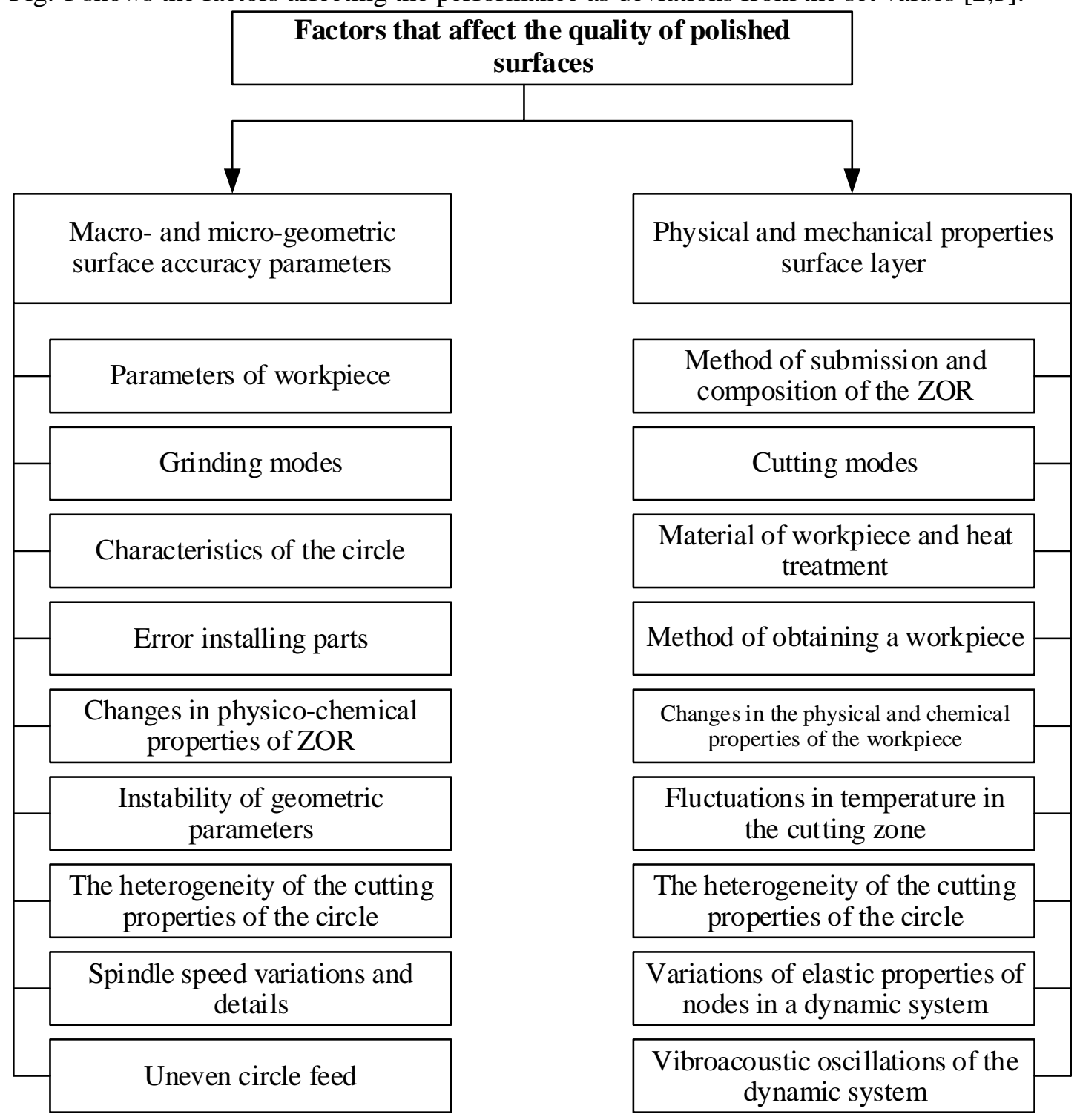

Fig. 1 Factors affecting the quality of grinding surfaces

Identifying process parameters that must be controlled in order to effectively manage this process is a challenging task, depending on the requirements as to accuracy and the nature of relationships between the parameters of the grinding process [4] and indicators of quality of the parts. 
Therefore the choice of algorithm and block diagram of the control precision processing generally performed in the following sequence [5]:

1. Establish the causes and size range of dispersion parameters and processing conditions.

2. Development of a mathematical model of grinding process and the process of forming processing errors [7].

3. Analytical study and determine the grinding process control parameters. Formation of requirements to the structure of the cycle, the nature of the procedure to the block diagram and precision process control system.

4. Experimental investigation of the grinding process for the purpose of studying the complex relationships between parameters of technological systems and processing parameters.

5. Development of control algorithm and process control systems for managing its implementation.

Review and analysis of previous studies. Analyzing the formation of error handling, the following main components of total error $\Delta_{\Sigma}$ processing one piece [6]

- error $\Delta_{\Pi}$ active control system, which is defined as the difference between the actual size parts in the time of the team and given size;

- error $\Delta_{\theta}$, caused by temperature deformation of the workpiece;

- $\Delta_{c}$ error caused the delay time $t_{c}$ executive team on the withdrawal of the grinding wheel is determined by:

$$
\Delta_{c}=\int_{0}^{t_{c}} v_{s}(t) d t
$$

where $\mathrm{v}_{s}$ - speed removal allowance.

To assess the impact of rate changes $v_{д}$ size controlled by error handling is advisable to allocate a part $\Delta_{\Pi}$ error $\Delta_{t \Pi}$ caused by time delays $t_{\Pi}$ active control system, or in other words, the delay time change measuring signal changes relatively controlled size:

$$
\Delta_{t_{M}}=\int_{0}^{t}\left[v_{\bar{Z}}(t)-\frac{1}{i_{\sigma}} v_{\text {вนи }}(t)\right] d t,
$$

where $\mathrm{v}_{\text {вим }}$ - the rate of change of the measuring signal;

$i_{B^{-}}$- the sensitivity of the measurement system.

To determine the analytical errors $\Delta_{t I I}$ and $\Delta_{c}$ need to know the patterns of change of speed $v_{s}$ removal allowance as a function of time and current handling allowance value $\Delta D$. Excluding the impact of the rate of change of temperature deformation of details, we can assume that $v_{s}=v_{д}$.

Analytical study of error $\Delta_{\Pi}$ fraught with difficulties. In addition, this error does not depend on the selected control algorithm grinding process. Therefore, the theoretical studies of precision processing error $\Delta_{\Pi}$ taken the same for all processes.

For external grinding thin rings in error $\Delta_{\Sigma}$ includes another component $\Delta_{F}$, deformations caused by force details.

The numerical value $\Delta_{F}$ with minor deviations determined by the equation:

$$
\Delta_{F}(t)=F_{y}(t) \frac{R_{C K}^{3}}{4 E J}\left(\frac{4}{\pi}-\varphi \sin \varphi-\cos \varphi\right),
$$

where $F_{y}(t)$ - instantaneous value of the radial cutting force;

$R_{c k}$ - average radius of the ring;

$\varphi$ - the angle formed by the line measurement and line of action of the radial cutting force.

Presenting main material. Based on the theoretical foundations of automatic control grinding cutting process can be considered as an inertial link [4]. It is assumed that the inertia of a system of elastic grinding machine several orders of magnitude smaller than the inertia of the grinding process, the coefficient cutting grinding wheel $K_{p}$ properties within each processing stage of the cycle remains the same width and grinding is also constant. [5] In this case, the variation speed removal allowance can be described following differential equation:

$$
T_{p} \frac{d v_{s}}{d t}+v_{s}=K v_{6}
$$

where $v_{\sigma}$ - velocity wheelhead (internal grinding - doubled its value);

$K$ - gain, depending on the ratio of the velocity $v_{s} / v_{\sigma}$ in the steady grinding, ie for $t>3 T_{p}$.

The process mortise grinding bearing rings circle line wear is negligible and, therefore, take $\mathrm{K}=1$.

Solving equation (4) with initial conditions $t=0$ and $v_{s}=v_{s n}$, we get:

$$
v_{s}=v_{6}\left(1-e^{-\frac{t}{T}}\right)+v_{s n} e^{-\frac{t}{T_{p}}} .
$$


Integrating equation (5) for the initial conditions $t=0$ and $S=S_{n}$, find an expression for this allowance, which is removed during polishing,

$$
S=S_{n}-v_{\sigma} t+T_{p}\left(v_{\sigma}-v_{s n}\right)\left(1-e^{-\frac{t}{T_{p}}}\right) .
$$

The equations allow to analyze the change in $S(t)$ and $v_{s}(t)$ at each stage grinding [8]. At the cutting stage and nursing equations describing the laws of removal allowance and rate of removal can be derived from equations (4) and (5) substituting them according $v_{s n}=0$ i $v_{\sigma}=0$.

Dependence $v_{s}=f(S)$ analytically determined only at the stage of nursing:

$$
v_{s}=v_{s n}-\frac{s_{n}-s}{T_{p}}
$$

For the remaining stages of grinding, which $v_{\sigma} \neq 0$ and dependence $v_{s}=f(S$ is determined by the type of transcendental equation (5) can find the approximate analytical solution of equations and connecting $v_{s}$ and $S$

For this resulted above equation is replaced by an exponential $e^{-\frac{t}{T}}$ function approximating a member of the species $\varphi(t)=-a t+b$. The approach is performed by least squares. The most common is an approximation $\varphi(t)$, for which the lowest value is:

$$
M=\int_{t_{1}}^{t_{2}}[f(t)-\varphi(t)]^{2} d t .
$$

To find the parameters $a$ and $b M$ derived from each of the parameters are equal to zero:

$$
\begin{aligned}
& \frac{1}{2} \frac{\partial M}{\partial a}=\int_{t_{1}}^{t_{2}}\left[-a t^{2}+b t-t e^{-\frac{t}{T}}\right] d t=0 ; \\
\frac{1}{2} \frac{\partial M}{\partial b}= & \int_{t_{1}}^{t_{2}}\left(-a t+b-e^{-\frac{t}{T}}\right) d t=0 .
\end{aligned}
$$

The equation approximating functions in general written as $\varphi(t)=-a_{1} \frac{t}{T}+(1-b)$. Numerical values $a l$ and $b$ are defined set boundaries approximation interval $t_{1}$ and $t_{2}$, which are set based on the largest and smallest processing time at the test stage grinding. It is clear that the narrower interval approximation, the more accurate the resulting equation describes the real dependency [6].

As a result of the approximation equation changes as a function $v_{s}$ allowance, for example, during cutting is:

$$
v_{s}=\frac{1}{1-a_{1}}\left(a_{1} \frac{s_{n}-s}{T_{p}}+b v_{\sigma}\right) .
$$

These equations are valid for minor errors of form parts and satisfactorily describe changes in laws $v_{s}(t)$ and $S(t)$ at the finishing stages of grinding. But in the early stages of polishing the change rate largely depends on the nature and source of errors workpiece shape [6].

Research transient cutting internal centreless grinding of details showed that the initial grinding cutting process differs significantly from that described by equation (4). Fig. 2 shows the curve of dynamic error $\Delta_{v}$ and $\Delta_{\theta}$ temperature error in the function allowance $\mathrm{Z}$, left on processing the results of analytical studies.

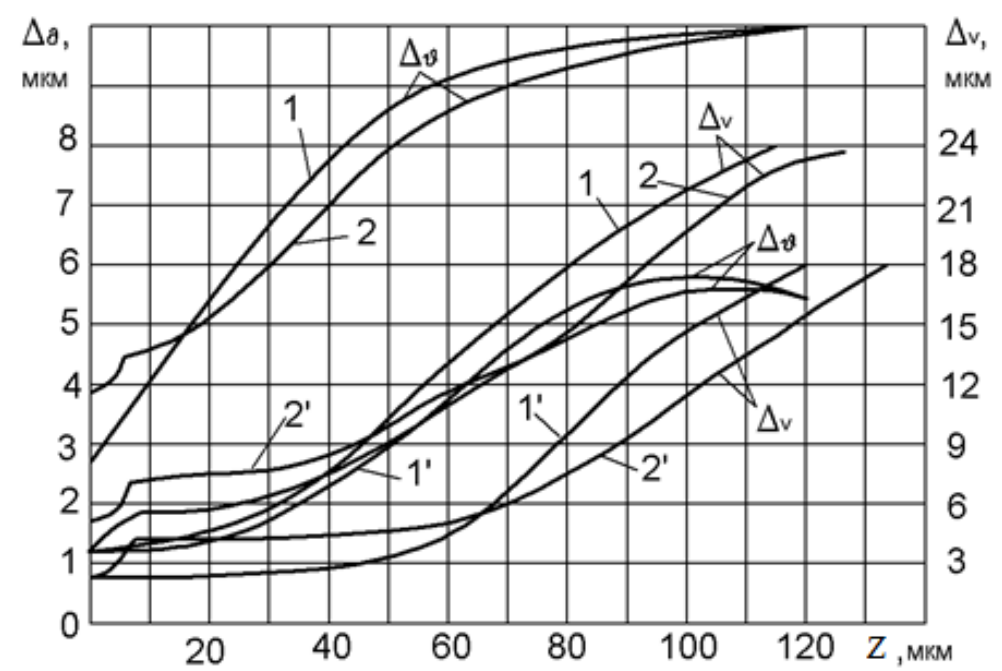

Fig.2. The dependence of temperature and dynamic error of allowance for extreme values of the parameters of the cutting process 
In the initial period of grinding allowance is only removal of the treated surface appearances [5]. The time for which the grinding wheel will always be in contact with the workpiece, ie the time dotorkuvannya the bottom cavity, defined as:

$$
t_{\partial o m}=\Delta_{\phi \sigma} / v_{\sigma}
$$

where $\Delta_{\phi \sigma}$ - output error shape of the workpiece, which is determined, for example, for centreless grinding as the largest riznostinnist details.

For grinding of filing for accelerated $v_{n p}$ time $t_{\partial o m}$ determined from the equation (11)

$$
\text { if } t_{\partial o m}<t_{n p}
$$

where $; t_{n p}=T_{p} \ln \frac{v_{n p}}{v_{n p}-v_{s}}$ - accelerated while cutting

$v_{s}$ - the rate of removal allowance for roughing included supply $v_{\sigma}$.

For $t_{\partial o m}>t_{n p} t_{\partial o m}$ time is given by:

$$
t_{\partial o m}=\frac{\Delta_{\phi \sigma}}{v_{\sigma}}+\left(1-\frac{v_{m p}}{v_{\sigma}}\right)\left[t_{\eta p}-T_{p}\left(1-e^{-\frac{t_{\eta p}}{T_{p}}}\right)\right]
$$

The error details in the form $t_{\partial o m}$ time, numerically equal to the elastic deformation $S_{n d}$ technological system to this point:

$$
\Delta_{\phi \sigma}^{\prime}=v_{\sigma} T_{p}\left(1-e^{-\frac{t_{\partial o m}-t_{n p}}{T_{p}}}\right)+v_{n p} T_{p}\left(1-e^{-\frac{t_{n p}}{T}}\right) e^{-\frac{t_{\partial o m}-t_{n p}}{T_{p}}} .
$$

and allowance, taken from speeches details during $t_{\partial o m}$ equals $\Delta_{\phi \sigma}-\Delta_{\phi \sigma}^{\prime}$.

Taking the time $t_{\partial о m}$ origin of the current value of the error form details the difference between the current value of the elastic deformation of the system during grinding and hollow speeches:

$$
\Delta_{\phi \sigma}(t)=v_{\sigma} T_{p}\left(1-e^{-\frac{t_{\partial o m}-t_{n p}}{T_{p}}} e^{-\frac{t}{T_{p}}}\right)+v_{n p} T_{p}\left(1-e^{-\frac{t_{n p}}{T_{p}}}\right) e^{-\frac{t_{\partial o m}-t_{n p}}{T_{p}}} e^{-\frac{t}{T_{p}}}-v_{\sigma} T_{p}\left(1-e^{-\frac{t}{T_{p}}}\right) .
$$

After the change:

$$
\Delta_{\phi \sigma}(t)=\Delta_{\phi \sigma}^{\prime} e^{-\frac{t}{T_{p}}}
$$

Equation (13) implies that the error $\Delta_{\phi \sigma}$, if $T_{p}$ remains unchanged, only a function of processing time.

If $t \geq t_{\partial o m}$, the current value of the average speed removal allowance

$$
v_{s}\left(T_{p}\right)=v_{\sigma}\left(1-e^{-\frac{t}{T_{p}}}\right)-\frac{\Delta_{\phi \sigma}^{r}}{T_{p}} e^{-\frac{t}{T_{p}}}
$$

Conclusions. The total error handling in grinding operations is complex, the main components are:

- own error active control devices that are included in automatic dimensional control;

- errors caused by temperature deformation at all stages of the dimensional parameters;

- errors caused by dynamic processes of the automatic control dimensional parameters.

To increase the accuracy of details dimensional parameters of rolling bearings can be based on optimal construction of the process for grinding vykinchuvalnyh processing operations.

Analyzing the calculated data and graphs can be drawn:

- qualitative relationship between the individual components of error processing can vary widely by changing conditions of processing, building cycle time grinding;

- the current value of the random component of the dynamic error $\Delta_{v}$ and grinding temperature error $\Delta_{\theta}$ to vykinchuvalnyh stages of processing are determined mainly by instability speed removal allowance, cutting the time constant strain and temperature details at the end of the rough grinding;

- stabilization of allowance removal rate is much faster stabilization of temperature deformations details. Therefore, in some cases the main factor limiting the reduction of time polishing the final stages are temperature error $\Delta_{\theta}$;

- nursing input stage after rough grinding allows you to assign a minimum allowance for fair grinding through removal during most of the nursing bed of fallen and significant reduction of errors in the form of processed holes. For removing minor fluctuations rate allowance at the end of the rough grinding $\Delta v_{s n}$ and time constant $\Delta T_{p}$ entering nursing rough treatment increases productivity. For relatively large values $\Delta v_{s n}, \Delta T_{p}$ and allowance for nursing $\Delta D_{6}$ чорн 
significantly increases the speed instability removal allowance and other deformities system VPID late stage grinding. Also increases the scattering of nursing time, time circle to supply parts after the revision;

- Developmental stage after the introduction of fair grinding ceteris paribus increases the supply of the clean and therefore reduce the wheel cart to detail;

- is the most productive cycle of nursing after rough grinding and finish (fourth version);

- for a relatively long time $t_{\text {uucm }}$, removing finishing allowance, the amount of temperature deformation of details at the end of treatment depends mainly on the size of the finishing feed.

Therefore, the limiting factor increasing the supply of clean, along with the factors listed above, may be allowed value of temperature error processing, primarily its systematic component. For relatively small values $t_{\text {niəв }}, t_{\text {чucm }}$ and editing time, temperature deformation of details at the end of treatment will depend also on their deformation temperature before entering the circle to edit.

\section{Інформаційні джерела}

1. Marchuk V., Hrynjuk S., Hrysjuk I. An analysis of intercommunications of technological factors is with indexes of quality of polishing operations // Technological Complexes. - Lutsk, 2017 №1(14) - p. 36-43.

2. Марчук B.I. Вплив технологічних чинників на експлуатаційні характеристики роликопідшипників // Наукові нотатки: Міжвузівський збірник (за напрямом "Інженерна механіка") Луцького державного технічного університету. 2003. Вип. 12. С. 179-184.

3. Марчук B.I. Про вплив конструктивно-технологічних чинників на параметри якості робочих поверхонь кілець роликопідшипників // Вісник Житомирського державного технологічного університету. 2003. Вип. 2(26). Том II. С. 106-108.

4. Марчук В.И., Михалевич В.Т., Терлецький Т.В.Эффективная система адаптивного управления точностью шлифования // Мир техники технологий. - Харьков, 2003 - №11 - С.5051.

5. Марчук В.И., Михалевич В.Т. Управление параметрами качества рабочих поверхностей колец конических роликоподшипников // В сб. Физические и компьютерные технологии в народном хозяйстве. Труды 5-й международной научно-технической конференции. Харьков: ХНПК «ФЭД», 2002. - С. 127-130.

6. Марчук В.І., Михалевич В.Т. Корекція деформаційних похибок при управлінні точністю механічної обробки // Наукові нотатки: міжвузівський збірник (за напрямком "Інженерна механіка"). - Луцьк: Луцький державний технічний університет, - 2000. Вип.7. - С. 143-145.

7. Равенець Л.М., Марчук В.І., Марчук С.В., Марчук І.В. Моделювання динаміки процесу безцентрового шліфування кілець роликопідшипників. Збірник наукових праць Перспективні технології та прилади, Випуск № 3, Луцьк.: Вид-во ЛНТУ, 2013.-С.72-78/

8. Ravenets L., Mechanism of origin of structural vibrations in conical roller bearings / Świć Antoni,Marchuk V.I., Marchuk S.V., Ravenets L.M. // ADVANCES IN SCIENCE AND TECHNOLOGY RESEARCH JOURNAL - 2014, nr 23, vol. 8, s. 68-72 [MNiSW: 5].

9. Марчук І.В. Технологічне забезпечення точності шліфування поверхонь обертання підшипників / І.В. Марчук, А.М. Ештеіві, М.В. Олексин / Наукові нотатки: Міжвуз. зб. Луцького національного технічного університету (за напрямком "Інженерна механіка"). Вип. 57. - Луцьк: Луцький НТУ, 2017. - С. 123-127.

Марчук B.I., Гринюк С.В., Марчук I.В., Джугурян Т.Г. ${ }^{1}$

Луцький національний технічний університет

${ }^{1}$ Щецінська Морська Академія

\section{МОДЕЛЮВАННЯ РОЗМІРНОЇ ТОЧНОСТІ В АВТОМАТИЗОВАНІЙ СИСТЕМІ ШЛІФУВАННЯ ПОВЕРХОНЬ ОБЕРТАННЯ}

В роботі розглядається вплив якості шліфованих поверхонь на формування їх розмірної точності на операціях шліфування кілець роликопідшипників. Прочес різання шліфуванням на автоматизованих верстатах можна розглядати як інериійну ланку. Сумарна похибка оброблення на шліфувальних операчіях має комплексний характер.

Ключові слова: похибка, роликопідшипники, иліфування, точність, деталь. 
Марчук В.И., Гринюк С.В., Марчук И.В., Джугурян Т.Г. ${ }^{1}$

Луцкий национальный технический университет

${ }^{1}$ Щецинская Морская Академия

МОДЕЛИРОВАНИЕ РОЗМЕРНОЙ ТОЧНОСТИ В АВТОМАТИЗИРОВАННЫХ СИСТЕМАХ ШЛИФУВАННЯ ПОВЕРХНОСТИ ВРАЩЕНИЯ

В работе рассматривается влияние качества илифованных поверхностей на формирование их размерной точности на операџиях шлифования колеи роликоподиипников. Прочесс резки шлифовкой на автоматизированных станках можно рассматривать как инериионное звено. Суммарная погрешность обработки на шлифовальных операчиях имеет комплексный характер.

Ключевые слова: погрешность, роликоподшипники, илифовка, точность, деталь. 